\title{
The evolution of the ancestral voice that always was and always will be
}

\author{
Kerri Simpson
}

University of Technology Sydney, Faculty of Arts and Social Sciences, PO Box 123, Ultimo

NSW 2007, Australia. kerri.simpson@student.uts.edu.au

\begin{abstract}
In our stories, we carry the concept of voice in various forms. In the context of contact the Indigenous 'voice' is one ever-present and evolving. It is omnipresent, laying down new foundations for the 'voice' through to new generations. It is the representation of an entire culture. It is not a natural language or the voice of academia. It is as ancient as its land and lies at the heart of its peoples. It is a cultural voice. It is the voice of the dreaming. It is the voice of resistance. It is the voice of self-determination.
\end{abstract}

Key words: Indigenous; Australia; voice; political; forms

\author{
We will go forward and learn. \\ Not swamped and lost, watered away, but keeping \\ Our own identity, our pride of race. \\ Pour your pitcher of wine into the wide river \\ And where is your wine? There is only the river.
}

- Oodgeroo Noonuccal

In the most recent calls for Indigenous 'voice' and recognition, the 2017 National

Constitutional Convention gathered 250 Aboriginal and Torres Strait Islander delegates to create the Uluru Statement from the Heart. The statement calls for constitutional reform, a 'First Nations Voice' entrenched in the Australian Constitution and the establishment of a 'Makarrata Commission'. The commission will supervise and negotiate agreement making between governments and First Nations' people, and the truth-telling of Australian history. The proposal for a 'voice' in federal parliament is challenged with stonewall defiance misguided by the confusion of what exactly the voice is. The notion of 'voice' is not a sudden emergence; it is complex and abstruse. This is because the now politicized concept is an 
ongoing action of modification. Throughout Australia's history, when confronted with contact, the 'voice' becomes reinvented and modifies its rhythm and forms according to its circumstances to overcome unfairness and exploitation.

In this essay, I will map various strategies of Indigenous 'voices' throughout the timeline of Australian history and explore the complexities of 'voices' which make it difficult to translate into academic language yet liberating for Indigenous and non-Indigenous people in its everpresent evolving determination.

\section{Indigenous 'voices' in the resistance to British colonialism}

Matters of recognition for Indigenous 'voices' preceded the establishment of a system of federalism in Australia. The confrontation of early colonial frontier violence is still a process of on-going resistance due to dismissal and silence of Indigenous experiences (Morris 1989, p. 7). This process did not cede Indigenous 'voices' demanding recognition but rather resulted in forms of Indigenous-led resistance to colonial power.

From 1788-1928, the custodians of ancient lands had been subjected to colonial violence and massacres in the British Empire's pursuit of imperialism and colonial settlement: known as The Frontier Wars. Goodall states in the activity of colonisation, Aboriginal society developed counteractive forms of strategies for creating a future in the very changed conditions faced (1995, p 55). In 1788, it is estimated that over 750,000 Aboriginal people had occupied the continent of Australia which had been reduced by around 90 per cent by the turn of the 20th century. These massacres, later identified as genocide, where conducted by military action and private massacre parties. In the battlefield of frontier violence nationwide, Indigenous warriors stood at the frontline of The Frontier Wars, resisting the incursion of white settlers onto traditional lands and sea inhabited by already existing Aboriginal societies for millennia. The resistance then grew in response to the scare and pace of the invasion (Goodall 1995, p. 65).

One of the significant Indigenous figures of resistance against European colonists is Pemulwuy, a Bidjigal warrior of the Darug Nation, from the Botany Bay area of Sydney. In 1792, after a series of ongoing violence towards Indigenous people, Pemulwuy led a 12-year war of resistance in retribution for the violent treatment of his people that ended with his execution. Indigenous members of Gandangara too faced 'punitive expeditions' and a final massacre at Appin in 1816 known by Governor Macquarie the most revered of all governors from the white colonist perspective. They were able to demonstrate enough resilience to overcome this onslaught to regroup. By 1876, they were able to recover a portion of their land in the Burragorang Valley. Through negotiations they developed a farming base to which they were able to work independently until the 1920s (Goodall 1995, p. 65).

Independence and recognition have always been central concepts demanded by traditional owners. Goodall discusses the early demands for land claims that were put onto paper which consistently made three points. Firstly, cultural economic independence by hunting or

NEW: 2019 
farming was desired without the interference of white invaders. Secondly, this economic independence was not for capital gain but rather posterity. And thirdly, they wanted land within their own country, traditional lands that had long belonged to their ancestors (1995, p. 66). The rapid growth of industrialisation in Britain and capitalist means of production created markets that poured the fuel for investment in rural industries; this need provided, however unethical, the rationale for seizing Indigenous land. Capitalism pointed the gun of colonisation. These parochial viewpoints of European colonizers and the rapid development of a land-extensive economy made it impossible for dissimilar world-views to co-exist (Morris 1989, p. 10). Since 1788, the socio-political narrative of Australia combined with colonial force impacted the shaping of the voice and the representation of it within the nationalist project of a white Australia.

\section{The turn of the 20th century and the turn of the 'voice'}

On 1 January 1901, six separate self-governing British colonies agreed to unite and form the Commonwealth of Australia and establish a system of federalism in Australia. The federation was a galvanising influence into a national campaign for Aboriginal civil rights and the establishment of Indigenous political footprints on Australian society. This meant that Aboriginal resistance became not pockets of defiance but national campaigns over the next century and which continues on.

The first formal national protest by Indigenous Australians occurred in 1938 during the 150 th anniversary that first marked European seizure of Indigenous traditional lands and the beginning of anguish and degradation imposed onto them. The National Day of Mourning organised by the founding members of Australian Aborigines' League and Aborigines Progressive Association was attended by Indigenous activist from across Australia. In their 1938 manifesto, 'Aborigines Demand Citizen Rights!', New South Wales Aboriginal activists Jack Patten and Bill Ferguson wrote: 'We ask - and we have every right to demand that you [white Australians] should include us, fully and equally with yourselves, in the body of the Australian nation'. This organised event appealed to the Australian nation to make new laws for the education, the care of Aboriginal people and granting full citizen status and equality along with the presence of Indigenous leadership in the Commonwealth parliament (McGregor 2009, p. 345).

The 1960's was a time for significant change in Australia. In 1965, Aboriginal activist Charles Perkins led a bus tour of western and coastal NSW along with a group of white sympathetic University of Sydney students to draw public attention to deplorable conditions of Aboriginal health, education, inadequate housing and other forms of discrimination. Drawing on the civil rights movement of the US, university students carried out the Freedom Rides in rural NSW, where racism was long-standing and entrenched. For Indigenous and non-Indigenous activists, the objective of the Freedom Rides was to elevate public consciousness of Indigenous people living in one of the wealthiest countries but not participating in it and to see for themselves the conditions of life for Indigenous people (Ginsburg 2006, p. 32). The period then saw the voice of non-Indigenous activists of good

NEW: 2019 
will and conscience also joining in with the Indigenous voice in pursuit of social justice. Interestingly, white voices also emerged not only in NSW but nationally, significantly at the Gurindji strike at Wave Hill rallying to the support Indigenous brothers and sisters for civil justice.

After ten years of campaigning, Australia went to the polls in the biggest 'Yes' vote in Australian history to alter the Australian constitution. The Federal Council for the Advancement of Aborigines and Torres Strait Islanders served as a vital community voice to secure social transformation in a society which had always rejected them (McGregor 2009, p. 346). The Referendum secured two fundamental changes: the repeal of a section disallowing the counting of Aboriginal people in the Commonwealth census, and granting the Commonwealth the power to legislate on behalf of Aboriginal people, which was only previously applied by the states. During and after the referendum some Indigenous voices praised the referendum as a transformative moment for Indigenous rights; other voices found the process redundant and offering little. There was logic in both voices. Chicka Dixon and Charles Perkins both saw the referendum not only as a historical moment for non-Indigenous Australia but also symbolic in the representations of agency and power. For Chicka Dixon, 'For most Aborigines [the referendum] is basically and most importantly a matter of seeing white Australians finally, after 179 years, affirming at last that they believe we are human beings'. Charlies Perkins wrote, the referendum 'is the moment of truth - whether the white people really are interested in our welfare or rights' (Attwood 1997, p. 50). On the other side of the fence, many politically active Indigenous people thought the 1967 political endeavour was more peripheral to issues Indigenous people were currently facing. In Shirley Smiths' words, the referendum 'didn't seem to have anything to do with Aboriginal people' and the immediate problems of their everyday life' (Attwood 1997, p. 53). Looking back with the wisdom of historical hindsight, the truth is between those two positions. In any case, High Court decisions such as in the Hindmarsh Bridge case showed the limitations of what was achieved in diluting the words in the sections 51 (xxvi) and 127 of the constitution.

The significance of a few of these 'voices' confronting discrimination in a white racialized political environment created their own representations of what contemporary indigeneity might look like for itself and for the Australian public (Ginsburg 2006, p. 34). McGregor adds to this argument describing the emergence of a new generation and new ideologies, turning away from the inclusionist ideal and emphasising one of distinction (McGregor 2009, p. 347). These calls for voice have been sharpened through the experimentation in various forms of opposition.

\section{The ethereal 'voice' of the black poets}

With the emergence of the Indigenous activist arts scene, the ancestral ever-changing voice comes out in different forms according to the socio-cultural environment in which it needs to be stated. The resonance of the 'voice' becomes one of antiquity, drawing on the deep wells of its past. It is translated down through the generations, from the loud rubbles of political life to the vibrant descriptions of the gentle poet. Storytelling and performativity are modes used

NEW: 2019 
by Indigenous people as forms of expression deeply embedded in Indigenous culture and forms that are most comfortable (Ginsburg 2006, p. 29).

In the 1970s in Redfern, political activism took to the stage with the first Indigenous theatre company. The National Black Theatre performed comedic and political sketches opening doors for non-Indigenous audiences to get an insight into the perspectives of the Indigenous person in Australian society. Ginsburg describes the increasing self-consciousness of the Indigenous arts scene that sought to crack the distorted mirror that has been held up to them that reflected unfairness and exploitation (2006, p. 29). Politically driven street performances were features of early works by the company which included a performance in which a wellknown Aboriginal activist who was beaten and arrested by Aboriginal actors dressed as police officers. In response to this performance, a lawyer had contacted the Aboriginal Legal Service with advice to release the Aboriginal person who had been arrested. Against these backdrops of street performances, the company provided a voice for the community and a reflection of their sentiment. In 1973, based on a satirical political revue of the same name, Basically Black, was the first all-Aboriginal television program written and created by Indigenous artists. Themes throughout Indigenous artistry examine and address the denial of human rights and the low-grade position of Indigenous people in Australian society to give visibility to lives that might otherwise go unnoticed, becoming a vessel for liberation (Ginsburg 2006, p. 29). Written by Indigenous playwright and poet Gerry Bostock, Here Comes the Nigger 1976, is the story about Sam, a young blind Aboriginal man, who is tutored by a young Euro-Australian. The central themes of the play explores' racism and sexism in Australia, projecting the activity of 'blindness' to which everyone has a degree of. Aboriginal activists were coming to see their position less as an excluded group seeking inclusion, and more as a colonised people seeking liberation (McGregor 2009, p. 352). Oodgeroo Noonuccal (Kath Walker) began her work as an Indigenous rights activist, poet, conservationist and educator during a time that encapsulated equal rights and opportunities for Indigenous people. Her work to decolonise Australia was written in her poetry that taught the spirituality of her ancestors, the rights for Indigenous people and the deep calling for reconciliation and unification, giving readers a glimpse into the qualities of this ancient 'voice'. Walker's self-proclaimed goal had been Aboriginal inclusion in the Australian nation on the basis of civic equality away from the quest for citizenship and inclusion, toward an emphasis on Aboriginal identity and solidarity typified Aboriginal activism in that decade (McGregor 2009, p. 347).

Oodgeroo's poem The Past is a reflection and reminder that for Aboriginal people, the past is a part of us and inscribed in how define our present identities culturally, socially and emotionally. The poem is a deep and contemplative look at the past and poses powerful questions regarding decisions for the future. The poem supports the idea of past and present interconnecting.

Let no one say the past is dead The past is about us and within

(Oodgeroo Noonuccal 1970) 
Surprisingly, in a cave in China, Kath Walker has the same strange feeling of interconnectedness of cultures; a mysterious feeling of the presence of her dreaming across vast oceans. In Flute Reed Cave she sees the possibility of the world-wide connection of that spiritual existence.

Her poem We Are Going centres around the themes of Aboriginal oppression, dispossession and cultural disinheritance. Throughout the poem, she criticizes the colonial force and disrespect of the white man dispossessing Indigenous peoples' right to cultural acceptance and ownership of land.

\footnotetext{
Notice of the estate agent reads: 'Rubbish May Be Tipped Here'. Now it half covers the traces of the old bora ring.

We are as strangers her now, but the white tribe are the strangers. We belong here, we are of the old ways.
}

(Oodgeroo Noonuccal 1964)

The legacy of the Indigenous 'voices' in the artistry they create across Australia's cultural and political landscape is not just of history but the shaping of it. These forms of artistry take on increasing significance as interventions into efforts to pathologize Aboriginal culture in the interest of neoliberal agendas (Ginsbury 2006, p. 43). These bodies of knowledge create an effective counter discourse in their holistic approach discussing various areas of Indigenous political and human life.

\section{Conclusion}

In colonial society and the political environment of Australia, the multifaceted and expressional dimensions of the 'voice' has made it too powerful and resilient to contain. To non-Indigenous opponents it can be quite confusing as its oppositional forms appear threatening but when analysed it is not necessarily any of those things. Now with 250 years of passed time with no treaty or constitutional recognition for the First Nations people of Australia, the proposal for a 'voice' to parliament has developed a critical theory edge that addresses the most vulnerable and least powerful members of a society. These voices would strengthen Australia's democracy, recognising two sovereign nations parallel to each other and needing each other. This process is the basis of genuine reconciliation. If Indigenous and non-Indigenous Australia does not provide a process that allows us to own up and confess to the details of Australia's past, we are at risk of a future repeating the same mistakes not just for Indigenous Australians but all Australians. The 'voice' is ancestral and liberating, part of a cultural transition passed down through memory with connection and ways of life forced into different forms by oppression. It always was and always will be. 


\section{References}

Attwood, B., 1997, The 1967 Referendum, or when Aborigines didn't get the vote, Canberra: Aboriginal Studies Press, pp. 49-63.

Ginsburg, F., \& Myers, F., 2006, 'A History of Aboriginal Futures' in Critique of Anthropology, Vol 26 (1), SAGE Publications, London, pp. 27-45.

Goodall, H., 1995, 'New South Wales' in A. McGrath (ed) Contested Ground: Australian Aborigines under the British Crown, St Leonards, NSW: Allen \& Unwin, pp. 55-120.

McGregor, R., 2009, 'Another Nation: Aboriginal Activism in the Late 1960s and early 1970s’, Australian Historical Studies, vol.40, no.2, September, pp. 343-360.

Morris, B., 1989, 'Colonial Domination as a Process of Marginalisation' in Domesticating Resistance: the Dhan-Gadi Aborigines and the Australian state, Oxford, Berg, pp. 6-30.

Oodgeroo Noonuccal 1970, 'The Past', The Past, poem.

Oodgeroo Noonuccal 1964, ‘We Are Going: Poems', We Are Going, poem. 